\title{
既存木造住宅の耐震補強事例を用いた耐震補強の費用対効果に関する試算 TENTATIVE CALCULATION OF COST-EFFECTIVENESS BASED ON SEISMIC RETROFITTING OF EXISTING WOODEN HOUSES
}

\author{
佐久間順三*，入江 康 隆** \\ Junzo SAKUMA and Yasutaka IRIE
}

\begin{abstract}
This paper describes the effectiveness of pre-repairing on total repairing cost prepared against earthquakes based on the seismic diagnosis and the seismic retrofit of thirteen existing wooden houses. We investigate the damage level by means of the relative displacement between upper and lower floors obtained by time-domain response analysis. The main results obtained from the investigations are as follows.

We show the regression equation between the pre-repairing cost and the disparity evaluated by seismic diagnosis of before and after seismic retrofit. After suffering the seismic damage, the necessary repairing cost of un-repaired house is about two to six times than that of pre-repaired house. This shows the effectiveness of pre- repairing on total repairing cost against earthquakes. Houses which evaluated low mark by seismic diagnosis have more effectiveness on total repairing cost.
\end{abstract}

Keywords : existing wooden house, seismic diagnosis, seismic retrofit, time-domain response analysis, damage level, cost-effectiveness

既存木造住宅，而震診断，而震改修，時刻歴応答解析，被害レベル，費用対効果

\section{1. はじめに}

1995 年「阪神淡路大震災」, 2004 年「中越地震」などによって多 数の人命が奪われるなどの未曾有の被害を受け, 2005 年, 中央防災 会議は「建築物の耐震化緊急対策方針」を策定し，住宅の耐震化率 を今後 10 年間で $90 \%$ までに引き上げることを，全国的レベルの目 標とした。その後, 2007 年「能登半島地震」, 2007 年「中越沖地震」, 2008 年「岩手宮城内陸地震」などの地震災害に見舞われ，多くの木 造住宅が倒壊などの被害を受け，既存木造住宅の耐震補強化が喫緊 の課題として，各分野で検討されている。
しかし，多くの研究者が発表している $5,7 \sim 9,11,12)$ ように，耐震 補強化は期待通りには進んでいない。遅延の原因がいくつか指摘さ れている。狩谷らは, (1)心理的側面の問題（意識の低さ), (2)補強費 用と補強効果の不透明性，(3)補強工事による日常生活への支障や手 間，(4)支援制度上の問題，等が主な原因であることを指摘している 2)。筆者らの実務経験からは，そのほかにも，設計施工実務者の知 識不足から発生する意識の低さが，重大な要因となっているのでは ないかと考える。

表 1 建物概要一覧

\begin{tabular}{|c|c|c|c|c|c|c|c|c|c|c|c|c|c|c|c|c|c|c|c|c|c|c|c|c|}
\hline \multirow{4}{*}{ № } & \multicolumn{16}{|c|}{ 建物概要一覧 } & \multicolumn{4}{|c|}{ 補強前 } & \multicolumn{4}{|c|}{ 補強後 } \\
\hline & \multirow{3}{*}{ 筑年 } & \multirow{2}{*}{\multicolumn{4}{|c|}{ 面積 $\left(\mathrm{m}^{2}\right)$}} & \multirow{3}{*}{ 屋根 } & \multirow{3}{*}{ 外壁 } & \multirow{3}{*}{ 既存耐震壁 } & \multirow{3}{*}{ 金物 } & \multirow{3}{*}{ 床 } & \multirow{3}{*}{ 基䃈 } & \multirow{3}{*}{ 劣化 } & \multirow{3}{*}{ 補胎壁 } & \multirow{3}{*}{\begin{tabular}{|l|} 
工期 \\
(日)
\end{tabular}} & \multirow{2}{*}{$\begin{array}{c}\text { 補強費用 } \\
(千 \text { 员) }\end{array}$} & \multirow{3}{*}{$\begin{array}{c}\text { 補強費用/ } \\
\Sigma \mathrm{A}\end{array}$} & \multirow{2}{*}{\multicolumn{2}{|c|}{ 2階 }} & \multirow{2}{*}{\multicolumn{2}{|c|}{ 1階 }} & \multirow{2}{*}{\multicolumn{2}{|c|}{$\frac{2 \text { 階 }}{2 \text { 方向梁 }}$}} & \multirow{2}{*}{\multicolumn{2}{|c|}{ 1階 }} \\
\hline & & & & & & & & & & & & & & & & & & & & & & & & \\
\hline & & 1階 & 2階 & 合計 & 2/1階 & & & & & & & & & & & & \multicolumn{2}{|c|}{ 2Iws(評点) } & \multicolumn{2}{|c|}{$11 \mathrm{ww}$ (評点) } & \multicolumn{2}{|c|}{2 2Iws(評点) } & \multicolumn{2}{|c|}{ 1Iws(評点) } \\
\hline 1 & 1979 & 58.76 & 53.83 & 112.59 & \begin{tabular}{|l|}
0.92 \\
\end{tabular} & 栈瓦葦 & モルタル & 筋加い $30 \times 90$ & \begin{tabular}{|l|l|l} 
無 \\
\end{tabular} & 合板 & 無筋コンクリート & 有 & 5 & 7 & 530 & 4,707 & 0.94 & 0.94 & 1.06 & 0.75 & 1.02 & 1.02 & 1.15 & 1.02 \\
\hline 3 & 1936 & 97.92 & 56.86 & 154.78 & \begin{tabular}{|l|}
0.58 \\
\end{tabular} & 土亘瓦 & 土塗壁 & 土塗壁 & \begin{tabular}{|l|l|} 
無 \\
\end{tabular} & 火打ち+荒板 & 玉石基䃈 & 有 & 46 & 30 & 3,052 & 19,718 & 0.50 & 0.46 & 0.35 & 0.40 & 1.18 & 1.36 & 1.02 & 1.08 \\
\hline 4 & 1975 & 49.70 & 37.26 & 86.96 & \begin{tabular}{|l|l|}
0.75 \\
\end{tabular} & 石綿スレート & モルタル & 筋加い $30 \times 90$ & \begin{tabular}{|l|l|l} 
無 \\
\end{tabular} & 火打ち+荒板 & 無筋コンクリート & 有 & 5 & 10 & 517 & 5,945 & 1.16 & 0.83 & 1.08 & 0.64 & 1.27 & 1.19 & 1.20 & 1.11 \\
\hline 5 & 1975 & 78.05 & 62.11 & 140.16 & \begin{tabular}{|l|l|}
0.80 \\
\end{tabular} & 栈瓦䔄 & モルタル & 筋加い $30 \times 90$ & \begin{tabular}{|l|l|l} 
無 \\
\end{tabular} & 火打ち+荒板 & 無筋コンクリート & 有 & 11 & 14 & 1,210 & 8,633 & 0.83 & 0.78 & 0.57 & 0.48 & 1.10 & 1.02 & 1.13 & 1.17 \\
\hline 6 & 1978 & 53.41 & 38.92 & 92.33 & 0.73 & 栈瓦菩 & モルタル & 筋加い $30 \times 90$ & \begin{tabular}{|l|l} 
無 \\
\end{tabular} & 火打ち+荒板 & 無筋コンクリート & 有 & 15 & 15 & 2,170 & 23,503 & 0.71 & 0.63 & 0.65 & 0.39 & 1.14 & 1.16 & 1.04 & 1.15 \\
\hline 8 & 74 & 114.28 & 37.26 & 151.54 & 0.33 & 栈瓦葦 & 土塗壁 & 土塗壁 & \begin{tabular}{|l|l} 
無 \\
\end{tabular} & 火打ち+荒板 & 無筋コンクリート & 無 & 9 & 17 & 860 & 5,675 & 1.10 & 1.05 & 0.38 & 44 & 1.10 & 1.05 & 1.11 & 12 \\
\hline 9 & 1976 & .36 & 53.83 & 9.19 & \begin{tabular}{|l|l|} 
& 0.71 \\
\end{tabular} & 石綿スレート & モルタル & 筋加い $30 \times 90$ & 無 & 火打ち+荒板 & 無筋コンクリート & 有 & 9 & 13 & 142 & 840 & 1.15 & 1.40 & 0.75 & 0.56 & 1.27 & 1.53 & 1.10 & 1.06 \\
\hline 10 & 1975 & 59.62 & 41.41 & 101.03 & \begin{tabular}{|l|l|} 
& 0.69 \\
\end{tabular} & 石綿スレート & モルタル & 筋汃い30×90 & \begin{tabular}{|l|l} 
無 \\
\end{tabular} & 火打ち+荒板 & 無筋コンクリート & 有 & 9 & 20 & 340 & 3,263 & 1.25 & 1.03 & 0.98 & 0.95 & 1.25 & 1.03 & 1.42 & 1.49 \\
\hline 11 & 1975 & 62.11 & 43.06 & 105.17 & \begin{tabular}{|l|l|} 
& 0.69 \\
\end{tabular} & 石綿スレート & モルタル & 筋力、い $30 \times 90$ & \begin{tabular}{|l|l|} 
無 \\
\end{tabular} & 火打ち+荒板 & 無筋コンクリート & 有 & 20 & 25 & 1,493 & 14,196 & 1.32 & 0.94 & 1.12 & 0.91 & 1.47 & 1.04 & 1.67 & 1.32 \\
\hline 12 & 1980 & 68.73 & 29.81 & 98.54 & 0.43 & 栈瓦葦 & 金属 & 筋が、30×90 & \begin{tabular}{|l|l} 
無 \\
\end{tabular} & 火打ち+荒板 & 無筋コンクリート & 無 & 12 & 15 & 1,071 & 0,869 & 1.21 & 0.62 & 0.65 & 0.61 & 1.21 & 1.01 & 1.21 & 1.09 \\
\hline 13 & 1981 & 72.04 & 45.55 & 117.59 & \begin{tabular}{|l|l|} 
& 0.63 \\
\end{tabular} & 栈瓦葦 & モルタル & 筋が、 $45 \times 90$ & 無 & 合板 & 無筋コンクリート & 無 & 12 & 16 & 2,061 & 17,527 & 0.98 & 1.14 & 0.83 & 0.65 & 1.16 & 1.14 & 1.15 & 1.04 \\
\hline & & & & & & & & & & & & 平均 & 13.54 & 21.46 & 1,645 & 13,972 & 0.97 & 0.90 & 0.76 & 0.62 & 1.21 & 1.16 & 1.23 & 1.1 \\
\hline
\end{tabular}

* (有)設計工房佐久間

** 宇都宮大学大学院工学研究科 准教授·工博
Sekkeikobo Sakuma, Ltd.

Assoc. Prof., Graduate School, Utsunomiya Univ., Dr. Eng. 
本論文では，耐震化遅延の要因の一つと言われている「補強費用 と補強効果の不透明さ」に着目し, 而震補強工事の費用対効果につ いて, 筆者らが実際に行った耐震診断, 耐震補強設計, 補強工事 13 事例（表 1 に示寸）を用いて, 分析を行い, その有用性を報告する。

なお, 本研究では, 50kine 程度の地震動が起こったことを前提と しており, 地震動の生起に関する不確実性や, また, 耐震補強後に 何年使用寸るかといった点は考慮に入れていない。

この論文の中で用いている耐震診断は，木造住宅の耐震診断と補 強方法一木造住宅の耐震精密診断と補強方法（改訂版）「発行 財団 法人日本建築防災協会」【以下，「基準」という】の中の一般診断法 に基づいて行われている。以下, 本論文内の診断に関する用語は「基 準」に用いられているものである。

分析手順の概要を図 1 に示す。まず，I．(1)事例 13 棟の耐震補 強前後の評点と, (2)補強工事費を算定する。II. (3)建物の骨格曲線 を求め, (4)それを復元力特性に変換し, (5)時刻歴応答解析により, 最大応答層間変形角を求める。III. (6) (7)応答層間変形角に応じた被 害レベルを決定し，8被害レベルに応じた必要改修工事費を算定す る。IV. (9)地震被害前に補強工事を行った場合と行わなかった場合 について, 地震被害後の必要改修工事費を比較し, 事前補強の有効 性，すなわち費用対効果を分析する。

\section{2. 耐震診断・耐震補強事例概要 (13 棟) 2-1 建物概要}

筆者らが 2005 年から 2009 年にかけて耐震診断・耐震補強設計 ・ 補強工事を行ってきた 13 棟の概要を表 1 に示す。№.3，7(表 1 で影 を付す)を除いたその他の建物の建築年は 1974 年から 1981 年まで となっており，所謂，「新耐震」以前の昭和時代の建物である。№.3， 7 は大正時代に建築されたものである。

№.3, 7 の屋根は土莫瓦屋根, 内外壁は土塗壁となっており, 「非 常に重い建物」となっている。その他は, 栈瓦莫屋根「重い建物」 が 6 棟, スレート屋根「軽い建物」が 5 棟となっている。№.3 は関 西地域山間部に建築されている。その他は, 関東地域に建築されて いるものである。№.3 は所謂伝統的工法住宅であり, 束石の上に直 接柱が設置されている石場建て工法で, 主な耐震要素は土塗り壁・ 貫である。№.7 は大正時代後期の木造住宅ではあるが, 石場建て工 法ではなく，無筋コンクリート造布基礎の上に土台が配置され，土 台は基礎にアンカーボルトで緊結されている。内外壁とも土塗壁で はあるが，一部，筋かいが設置されており，現在の在来軸組工法に 近似した工法となっている。№.8(表 1 で影を付す)は比較的新しい建 物（1974 年）ではあるが，内外壁とも土塗壁となっており，筋かい は設置されていない。無筋コンクリート造布基礎の上の土台は基礎 にアンカーボルトで緊結されている。その他の建物は所謂在来軸組 工法と言われるもので, 主な耐震要素は筋かいとなっている。鉄筋 探查機を用いて調查した結果, 基礎は無筋コンクリート造布基礎で あり，アンカーボルトが設置されていることを確認している。

\section{2-2 補強前の建物の診断結果}

一般診断法の必要耐力は「基準」の表 $3.3 「$ 床面積当たりの必要 耐力 $\left(\mathrm{k} \mathrm{N} / \mathrm{m}^{2}\right) 」$ を用いている。屋根仕様に基づいて「軽い建物」「重 い建物」「非常に重い建物」に分類している。す心゙ての建物は，狭小 間口，軟弱地盤，多雪地域，混構造に該当しないので，それらによ

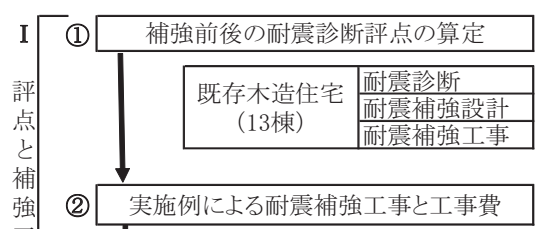

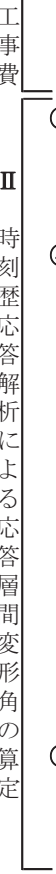

(3)

筆者が実際に而震診断・耐震補強設計・補強工事を 行った13事例の補強工事費を示寸。

骨格曲線の累加

各耐力要素の骨格曲線は「基準」による。各耐力要素 の骨格曲線を累加し、建物全体の骨格曲線とする。

(4) 復元力特性(骨格曲線)の作成

(3)で求めた骨格曲線を、応答解析用復元力特性モデ ルに変換する。五十田・河合モデルを参考とする。

$\mathrm{Q}(\mathrm{kN})$ (Y方向)1階

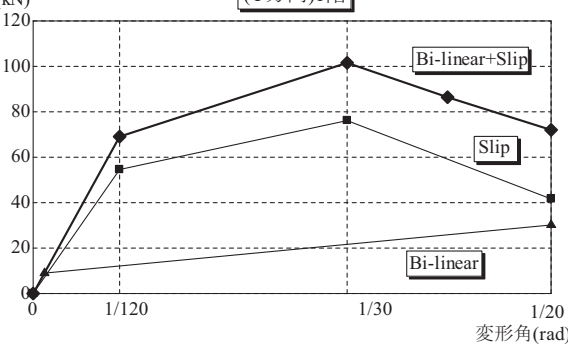

(5) 時刻歴応答解析により、応答層間変形角の算定

時刻歴応答解析ソフト(「Dynamic-PRO」ユニオンシステム 製)を用いて、最大応答層間変形角を算定する。

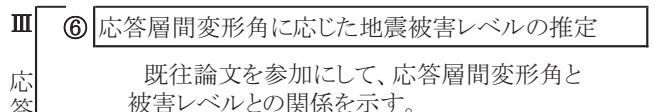

(7)地震被害レベルと必要改修工事費用

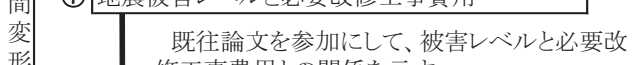

\begin{tabular}{l|l} 
変 & $\begin{array}{c}\text { 既往論文を参加にして、被害レ } \\
\text { 修工事費用との関係を示す。 }\end{array}$
\end{tabular}

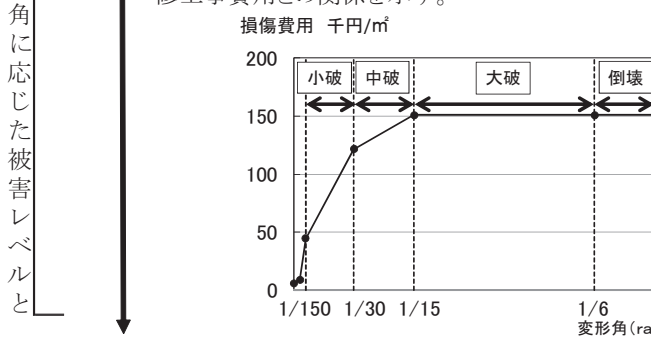

8) 各建物ごとの地震被害レベルと必要改修工事費用

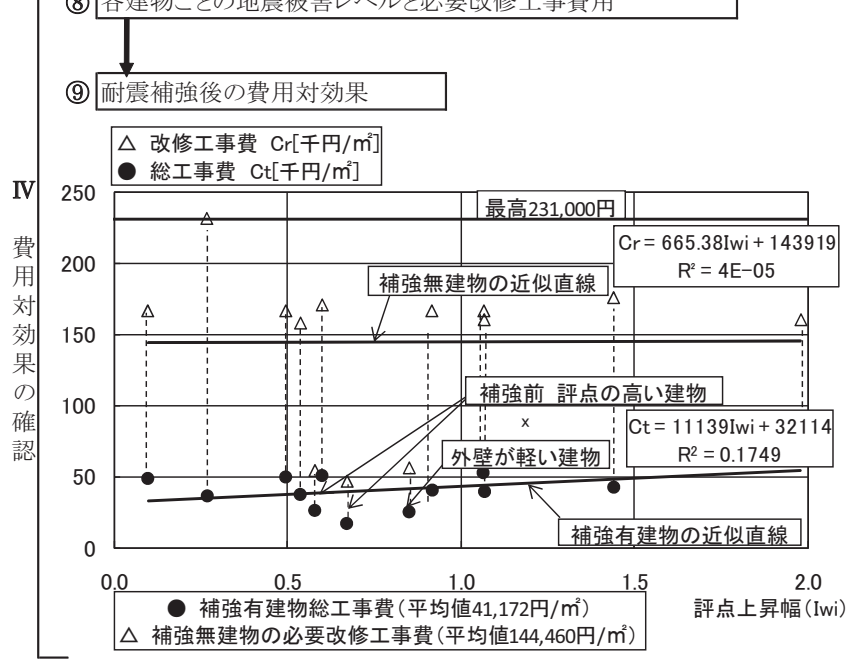

図 1 費用対効果の分析手順 
る必要耐力の割増は行なっていない。床下・天井裏・小屋裏などの 詳細な調查を行った結果, すべての建物の耐力要素は概放判明した ので, 所謂「不明な壁」は存在しない。各耐力要素の強さは「基準」 の表 3.5 「法と壁強さ倍率（k N/m)」に基づいて決定している。 筋かい端部・柱・梁接合部は, 釘またはかすがいで接合されている。 接合部による低減係数, 耐力要素の配置等による低減係数, 劣化度 による低減係数などは，「基準」に基づき算定している。

補強工事前の各建物の診断結果を表 1 に示寸。 1 階の評点は, $\mathrm{X}$ 方向 $0.35 \sim 1.06$, 平均值 $0.67, \mathrm{Y}$ 方向 $0.35 \sim 1.12$, 平均值 0.71 , となっている。評点が低い№.3, 7, 8 は, 耐震要素が土塗壁のみで, 強度が大幅に不足しているものである。評点の高いNo.10, 11 は, 大 規模開発団地内に建築されていて, 筋かいが多く配置されている強 度の高い建物である。

\section{2 - 3 補強後の建物の診断結果}

\section{2-3-1 補強方法}

耐震補強工法は，筋かい+構造用合板+金物補強，などの一般的に 普及している工法を用いている。代表的な補強方法を図 2〜4 に示す。 これらの方法は, 以下の (1)〜 (5)の利点がある。(1)材料費・施工費が 安価である。(2)一般的に普及している工法で, 誰でも知っていて, 作業が容易である。(3)誤った作業を行う危険性が少ない。(4)耐震性 能が明解である。(5)材料が入手しやすい。

特に強度, 剛性の低い№.3，7 の補強について説明する。№.3 は所 謂伝統的工法であり剛性・強度共に低い建物であり, 大地震時に大 きな水平変位が生じ，多大な被害を受ける恐れがあることから，図 4 に示寸構造用合板による耐力壁（強度・剛性・勒性にすぐれてい る)を用いて水平変位を小さくさせることとしている。1 階脚部が, 玉石の上部を滑ったり浮き上がったりしないように, 柱脚部を, 増 設した鉄筋コンクリート造底盤に金物で緊結している。№.7 は基礎 が建物周囲地盤よりも低くなり土に埋もれた土台や柱が蟻害を受け ていたことから, 図 4 に示寸ような建物外周部に鉄筋コンクリート 造布基礎を増設し, 建物全体を耐震補強している。既存部分の劣化 した箇所は撤去し新しい材料に取り換え, 劣化していない既存部分 には，薬剤散布などを行い，劣化の進行防止を行っている。

\section{2-3-2 補強後の建物の診断結果}

基本的には, 補強工事後の建物の目標評点を $1.0 \sim 1.2$ 程度として 設計している。これは，(1)大地震時の倒壊防止を主な目標として補 強を行うこととし, 多少の被害の出る小破・中破程度は許容寸る, (2)一般診断法による余裕度（精密診断法 1 より, 評点が低くなって いる。安全側である。）を考慮する, (3)施主一の経済的負担を軽減す る，などを考慮して決定されている。

補強工事後の建物の診断結果を表 1 右端に示す。 1 階の評点は, $\mathrm{X}$ 方向 $1.02 \sim 1.70$, 平均值 $1.21, \mathrm{Y}$ 方向 $1.02 \sim 1.67$, 平均值 1.17 , となっている。図 5 に補強前後の評点を示す。№.10, 11 は元々評点 の高い建物ではあるが, 施主の要望で評点 1.5 程度(倒壊しないレ心゙ ル)まで補強を行っている。№.3 は劣化が進行し, かつ強度の低い建 物であったことから，補強量を多くしている。

\section{2-3-3 補強工事費}

補強工事とは, 地震被災前にあらかじめ行う工事のことで, 表 1 に示寸補強工事費は各施工会社の補強工事に要した実費である。リ フォーム工事と合わせて行われたものが多い。全体工事費からリフ

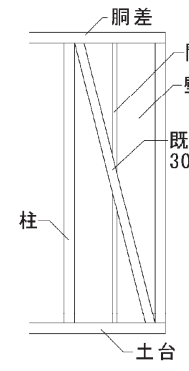

補強前

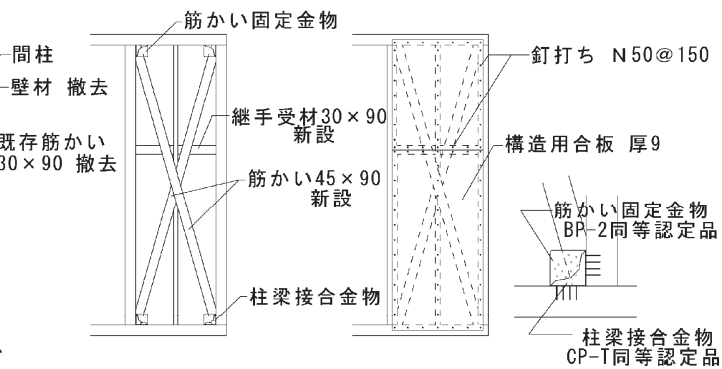

補強後 図 2 筋かい十構造用合板

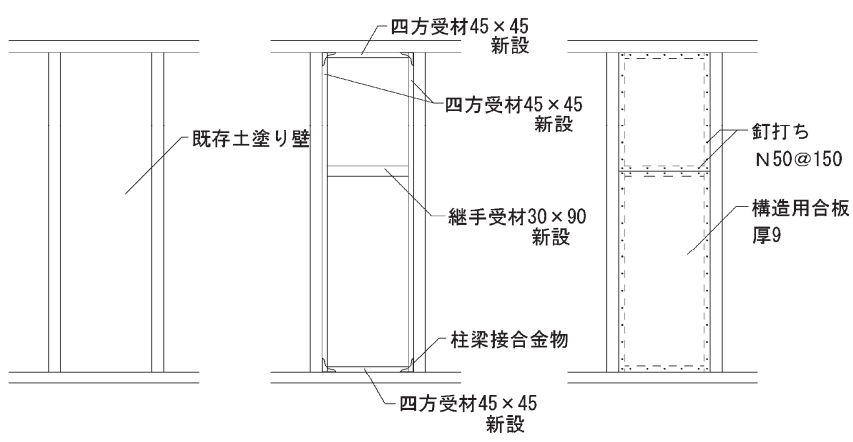

補強前
補強後

図 3 構造用合板

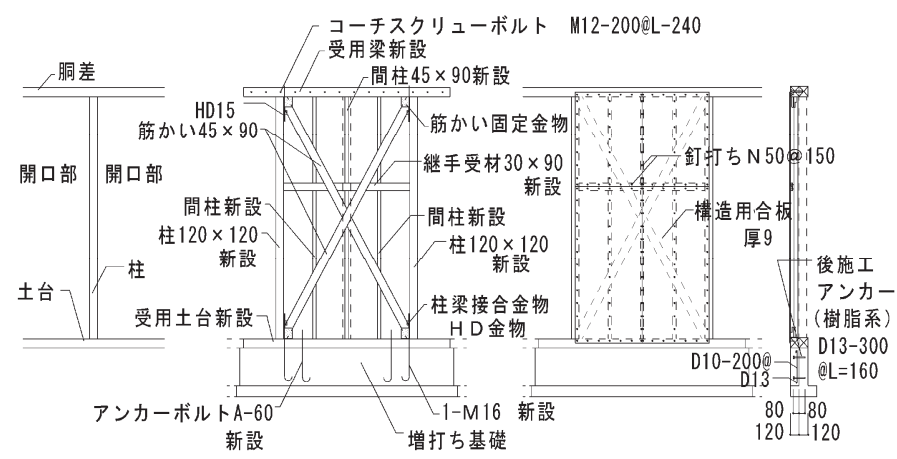

補強前

補強後

補強後

図 4 増設基礎十筋かい十構造用合板

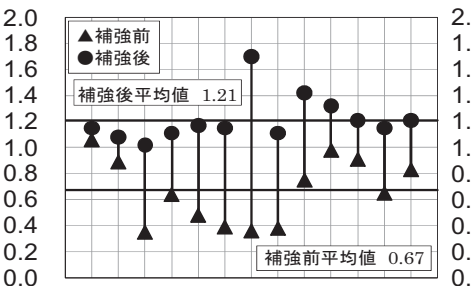

$\begin{array}{lllllllllll}0 & 1 & 2 & 3 & 4 & 5 & 6 & 7 & 8 & 9 & 1011121314\end{array}$ 1階 $x$ 方向 評点 建物No.

図 5 補強前後の評点

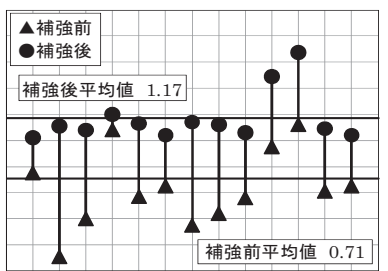

$\begin{array}{llllllllll}0 & 2 & 3 & 4 & 5 & 6 & 7 & 8 & 9 & 1011121314\end{array}$ 階 Y方向評点建物No.

オーム工事費を差し引いた金額を補強工事費としている。リフォー ム工事費と耐震補強工事費が明確に分離されていないものもある が，工事項目を確認しながら，概ね，仕分けることが出来た。

表 1 で示した補強費用と床面積当たりの補強費とを, それぞれ図 6,7 に示す。図 6,7 によればNo.3，7 の補強工事費が他と比べると， やや高額となっている。No.3，7 は大正時代に建築された古い建物で あり，補強前の建物評点が低く，耐震補強量が多くなったためであ る。表 1 から，補強工事費は 25.7 万円～ 568.83 万円（平均值 164.5 
万円）となっている。表 1 から, 床面積当たりの補強工事費は, 2,028 円 $/ \mathrm{m}^{2} \sim 46,726$ 円 $/ \mathrm{m}^{2}$ (平均值 13,972 円 $/ \mathrm{m}^{2}$ ) となっている。いずれ も, 大きなばらつきがある。これは, 評点の上昇幅(補強後の建物評 点から補強前の建物評点を差し引いた值）の違いなどによるもので ある。そこで, 方向別の評点上昇幅, 階数毎の評点上昇幅などを考 慮した評点上昇幅（以下の式）と工事費との関係を検討する。

$$
I w i=\frac{\left\{\left(I w_{02} \times 2-I w_{2 X}-I w_{2 Y}\right) \times A_{2}+\left(I w_{01} \times 2-I w_{1 X}-I w_{Y Y}\right) \times A_{1}\right\}}{\left(A_{1}+A_{2}\right)}
$$

Iwi：評点上昇幅

$\mathrm{IW}_{02}, \mathrm{IW}_{01}$ ：各階の補強後の建物の目標評点

$\mathrm{Iw}_{2 \mathrm{X}}, \mathrm{Iw}_{2 \mathrm{Y}}: 2$ 階 $\mathrm{X}, \mathrm{Y}$ 方向の補強前の建物評点

$\mathrm{IW}_{1 \mathrm{X}}, \mathrm{Iw}_{1 \mathrm{Y}} \mathrm{x}: 1$ 階 $\mathrm{X}, \mathrm{Y}$ 方向の補強前の建物評点

$\mathrm{A}_{1}, \mathrm{~A}_{2}$ : 各階床面積 $\left(\mathrm{m}^{2}\right)$

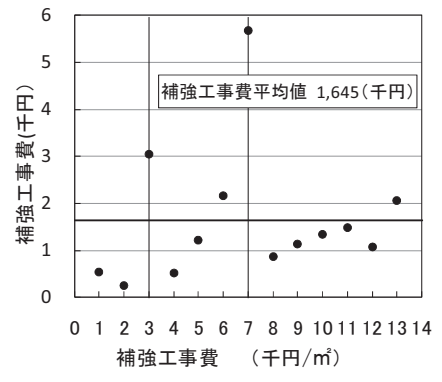

図 6 補強工事費 $\left(千 円 / \mathrm{m}^{2}\right)$

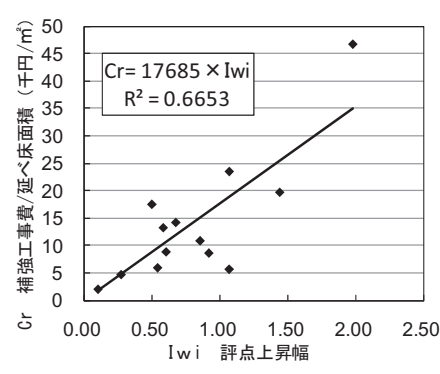

図 8 評点上昇幅と補強工事費

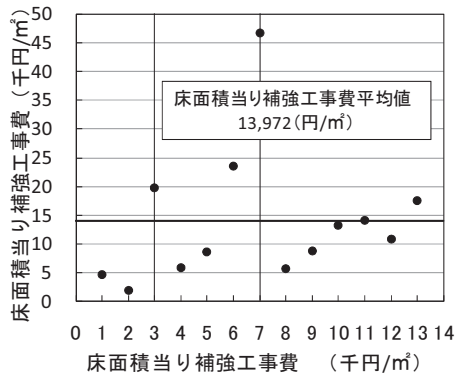

図 7 床面積あたり補強工事費

$\left(\right.$ 千円 $\left./ \mathrm{m}^{2}\right)$

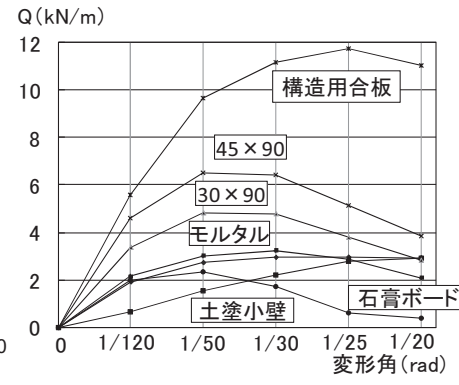

図 9 耐力要素の骨格曲線
図 8 に, 評点上昇幅（Iwi）と事前の耐震補強工事費との関係を示

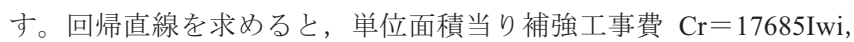
となっていて, 比較的良い相関が得られる（相関係数 $\mathrm{r}=0.82 ） 。 こ$ の式を用いると, 目標評点, 補強前の建物評点および床面積が決ま れば，補強工事費が概算でき、補強計画を行う時，補強工事費の目 安をたてることに役立つ。但し, このデータは軽い建物 5 棟, 重い 建物 6 棟, 非常に重い建物 2 棟を用いて作成しているものであり, それぞれの必要補強工事費が異なる可能性があるので, 補強計画に あたっては, 注意が必要である。この工事費には共通仮設工事費, 会社経費などの少額な固定費も含まれている。

補強後, 大地震に遭遇した時, どの程度の被害を受け, 改修費用 がいくら必要になるか, また, 補強していない時に, 大地震に遭遇 寸ると, どの程度の被害を受け, 改修費用がいくら必要になるかに ついて, 以下の手順で計算し, どちらがどの程度費用が安くなるか 確認する。

\section{3. 時刻歴応答解析による最大応答層間変形角 3-1 骨格曲線の累加}

各耐力要素の骨格曲線は「基準」資料編 4.2 「一般的耐力要素の 評価」に基づいて作成する。事例 13 棟に用いられた耐力要素（土 塗壁 $5.5 \mathrm{~cm}$ 未満, 筋かい $30 \times 90,45 \times 90$, モルタル塗り, 石膏ボ 一ド，構造用合板）の骨格曲線を図 9 に示寸。筋かいやモルタル, 石膏ボードは最大耐力発生後急激に耐力が低下寸るが，構造用合板 は急激な耐力低下はない。もともと強度の低い土塗壁は初期剛性も 低く, 塑性変形も大きい。既存木造住宅の主な耐力要素である筋か い $(30 \times 90$ 金物無し $)$ と，筋かい $(45 \times 90$ 金物有り $)+$ 構造用合 板の組み合わせによる耐震補強壁とを比較寸ると図 10 となり，強 度・勒性とも大幅に向上することが分かる。（耐力壁の骨格曲線は, 各要素の耐力の累加とする。)

建物全体の骨格曲線は，既往の論文（たとえば参考文献 8 など） に倣って図 9 に示した各耐力要素の骨格曲線に壁の長さを掛け，そ れぞれを累加することで求める。このようにして求めた建物N No.1 の 骨格曲線を図 11 に示す。筋かい $30 \times 90$ 金物無し，石膏ボード，モ ルタル壁の累加により建物全体の骨格曲線が作成されている。

№.3 のみ，土塗壁による小壁（腰壁・たれ壁）の骨格曲線を考慮 しているが，その他の建物には小壁の骨格曲線を考慮していない。 その理由は, №.3 の柱径が $12 \mathrm{~cm}$ 程度であり,「基準」資料編表 4.3 「垂れ壁付独立柱の荷重変形関係計算結果」を使用寸ることができ るが，その他の建物の柱径は $12 \mathrm{~cm}$ 未満であり，表 4.3 が使用でき ないためである。また, 小径柱は大地震時に折損し, 耐力が期待で きないと言われているためでもある。

なお，一般診断法方法 1 (その他の耐力： $0.25 \mathrm{Q}_{\mathrm{r}}$ ) を考慮して, 耐力を向上させて骨格曲線を作成している既往論文もある8）など。

強度や勒性が異なる各耐力要素を単純に累加してもよいという論 拠は，必ずしも明らかにされていないが，現状ではほとんどの既往 の論文において単純累加が採用されていることから，本論文におい てもそれらに準じて単純累加している。

\section{3-2 時刻歴応答解析用復元力特性（骨格曲線）の作成}

3-1 で作成した骨格曲線を，時刻歴応答解析用復元力特性に変換 する。五十田・河合により, 図 12 に示すような簡便で明解なモデ ルが提案されている 13)。これは，全体の骨格曲線をSlip 骨格曲線 と Bi-linear 骨格曲線に分解して Bi-linear+Slip モデルを作成した もので，木造住宅の振動の特性などを精度よく表現できるとしてい る。また, 仮動的応答実験との整合性を確認している。その他の論 文 7,8) でも同様のモデルが使用されている。五十田・河合モデルは, まず，降伏点荷重 Py を壁倍率 $\times 1.96 \mathrm{kN}$ とし，その他の各折り曲げ 点（強度・変位）を, 実験から得られた復元力特性の形に基づき設 定し, 最終的にBi-linear 骨格曲線と Slip 骨格曲線とを作成してい るものである。本論文では，五十田・河合モデルの骨格曲線の作成 手法を参考にして, 時刻歴応答解析用復元力特性を作成する。3-1 で作成した骨格曲線の層間変形角 $1 / 120$ 時の強度を降伏点と寸る。 また, 層間変形角 $1 / 30$ の時の強度を最大強度とする。図 11 に示寸 ように、実際の建物骨格曲線では層間变形角 $1 / 50$ の時, 最大強度と なっているが， $1 / 50$ 時と $1 / 30$ 時の強度がほぼ同程度であることか ら, 五十田・河合モデルに合わせて, 層間変形角 $1 / 30$ 時の強度を最 大耐力として、破線で示寸ような骨格曲線に修正している。その他 
$\mathrm{Q}(\mathrm{kN} / \mathrm{M})$

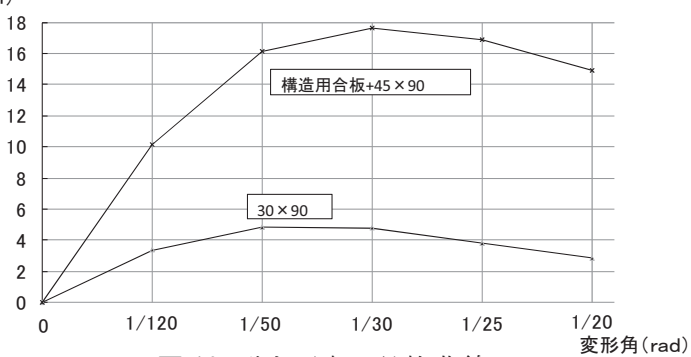

図 10 而讨力要素の骨格曲線

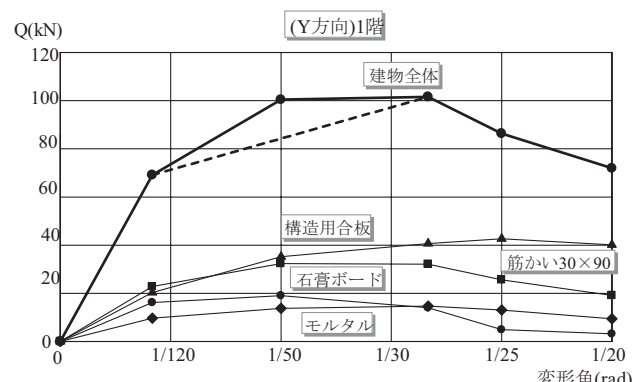

図 11 建物N No.1 全体の骨格曲線

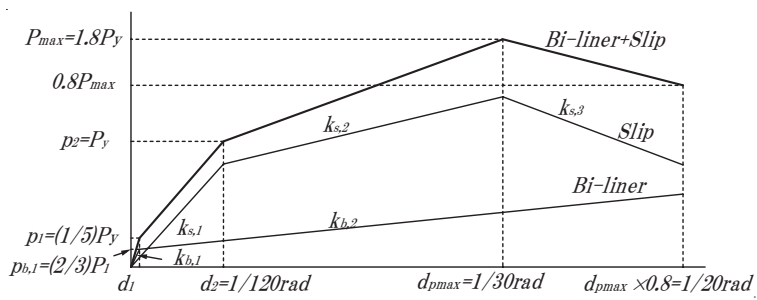

図 12 五十田・河合モデル

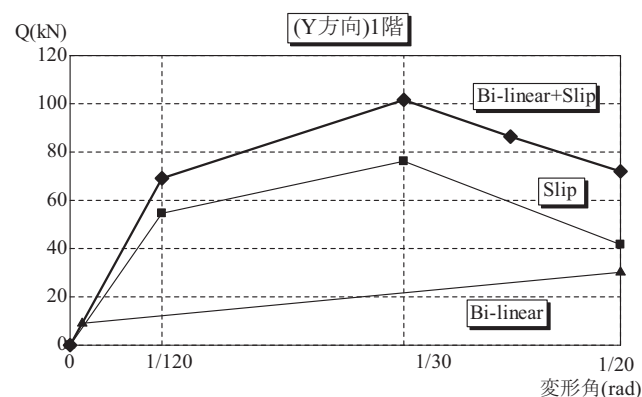

図 13 建物N No.1 の復元力特性

は五十田・河合モデルと同様のルールで, Bi-linear 骨格曲線と Slip 骨格曲線とを作成する。図 11 の骨格曲線を用いて、五十田・河合 モデル (Bi-linear+Slip モデル) に適合させながら、時刻歴応答解 析用復元力特性を作成し、図 13 亿示す。

\section{3-3 時刻歴応答解析による最大応答層間変形角}

解析モデルは 2 質点系せん断モデルとする。質量は「基準」3.3.1 必要耐力【解説】に記載されている「固定荷重・積載荷重」に基づ いて算定し、表 1 建物№.に合わせて、表 2 に質量の一覧表を示す。 応答解析は, 市販の応答解析ソフト (Dynamic Pro, ユニオンシ ステム株式会社）を用いて行った。解析方法は Newmark の $\beta$ 法（衝

表 2 質量と階高

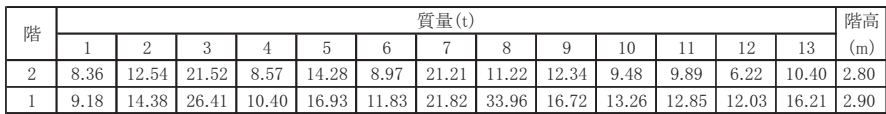

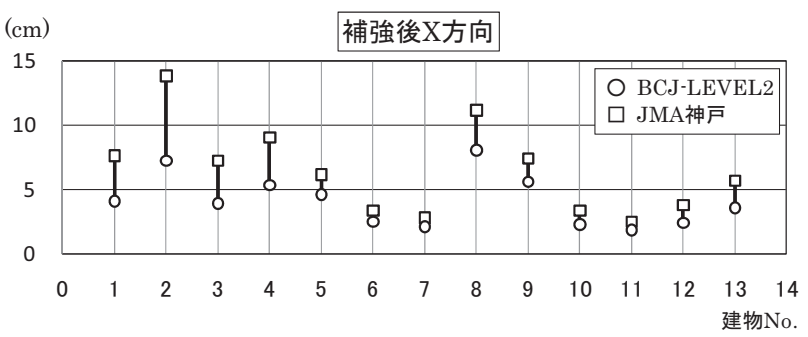

図 14 BCJ-LEVEL2 と JMA 神戸との忘答層間変位の比較
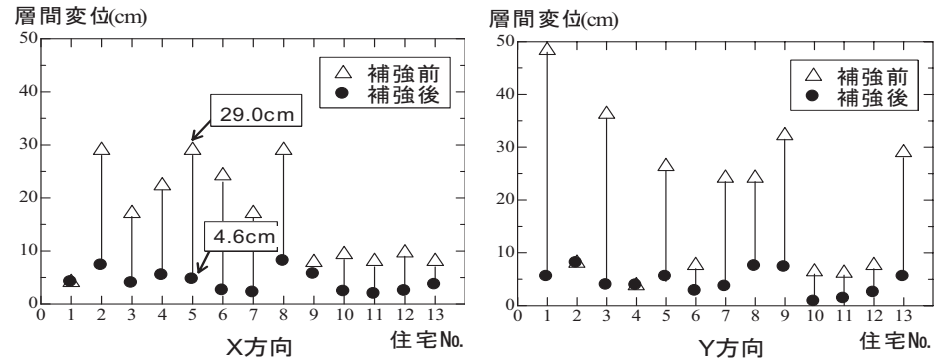

図 15 補強前の建物と補強後の建物の 1 階応答層間変位

撃加速度法）を用い，応答解析条件として，内部減衰定数は瞬間剛 性比例型とし，1 次固有周期に対する減衰定数を $5 \%$ としている。

大変形時では $\mathrm{P}-\delta$ 効果が影響することになるが，文献 $8,13,15$ においては，P- $\delta$ 効果を考慮せず応答解析されていることなどを参 考にして，本論文においても，P- $\delta$ 効果については考慮しないこと とする。 $\mathrm{P}-\delta$ 効果の影響については今後の検討課題とする。入力地 震波は BCJ-LEVEL2, JMA 神戸 NS 成分を用い，最大速度を 50 $\mathrm{cm} / \mathrm{s}$ としている。

時刻歴応答解析により求めた 1,2 階最大応答層間変形角の值を, 表 3 に示す。図 14 に示すように、JMA 神戸 NS 入力時の最大応答 層間変形角が BCJ-LEVEL2 と比較してやや大きくなっているが, BCJ-LEVEL2，JMA 神戸 NS 入力時の計算結果は概ね，同等とな っていることから，以下，BCJ-LEVEL2 入力時の計算結果を図化 した図 15〜20に基づいて検討する。

補強前後の 1 階最大応答層間変位の比較を図 15 に示す。補強前 建物の変位に比べて補強後建物の変位が小さくなっており, 補強の 効果が確認できる。例えば，No.5 では，X 方向の 1 階の応答層間変 位は補強前建物 $29.0 \mathrm{~cm}$ に対し, 補強後建物 $4.6 \mathrm{~cm}$ となっている。

1 階における評点と最大応答層間変形角との関係を図 16 (補強前 建物), 図 17 (補強後建物) に示す。図 16,17 では, ばらつきが 大きいが評点が低いほど 1 階最大応答層間変形角が大きくなる傾向 にあることがわかる。ばらつきが大きい主な原因は，基準の評点が 主に必要耐力と保有耐力とによって決定されることに対して，時刻 歴応答解析では剛性・変形性能の影響を受け，たとえ強度が高くて も復元力特性の性状によっては水平変位が大きくなったりするため である。図 16 において, 応答層間変形角が $1 / 10$ の建物の評点は, 0.38 から 0.89 とばらついており，相関があまり高くない。

図 18 に, 補強前建物と補強後建物の 1 階最大応答層間変形角の 関係を示す。すべて，補強後建物の 1 階最大応答層間変形角が補強 前建物のものよりも小さくなっている。值が同じものが 3 例あるが, これは耐震補強を行っていない方向である。図 19 に, 補強前建物 に対する補強後建物の評点比と最大応答層間変形角比との関係を示 
表 3 時刻歴応答解析による 1,2 階最大応答層間変形角と被害レベル

\begin{tabular}{|c|c|c|c|c|c|c|c|c|c|c|c|c|c|c|c|c|}
\hline \multicolumn{4}{|c|}{ No. } & 1 & 2 & 3 & 4 & 5 & 6 & 7 & 8 & 9 & 10 & 11 & 12 & 13 \\
\hline \multirow{12}{*}{ 補強前 } & \multirow{6}{*}{ BCJ-EVEL2 } & \multirow{2}{*}{ 2階 } & $\mathrm{x}$ & $1 / 169$ & $1 / 345$ & $1 / 9$ & $1 / 233$ & $1 / 271$ & $1 / 184$ & $1 / 12$ & $1 / 102$ & $1 / 185$ & $1 / 167$ & $1 / 142$ & $1 / 188$ & $1 / 165$ \\
\hline & & & $\mathrm{Y}$ & $1 / 269$ & $1 / 133$ & $1 / 138$ & $1 / 123$ & $1 / 196$ & $1 / 163$ & $1 / 16$ & $1 / 137$ & $1 / 213$ & $1 / 87$ & $1 / 148$ & $1 / 103$ & $1 / 199$ \\
\hline & & \multirow{4}{*}{ 1階 } & $\mathrm{x}$ & $1 / 71$ & $1 / 10$ & $1 / 17$ & $1 / 13$ & $1 / 10$ & $1 / 12$ & $1 / 17$ & $1 / 10$ & $1 / 37$ & $1 / 31$ & $1 / 36$ & $1 / 30$ & $1 / 36$ \\
\hline & & & & 小破 & 大破 & 中破 & 大破 & 大破 & 大破 & 中破 & 大破 & 小破 & 小破 & 小破 & 中破 & 小破 \\
\hline & & & $\mathrm{Y}$ & $1 / 6$ & $1 / 36$ & $1 / 8$ & $1 / 76$ & $1 / 11$ & $1 / 38$ & $1 / 12$ & $1 / 12$ & $1 / 9$ & $1 / 45$ & $1 / 47$ & $1 / 38$ & $1 / 10$ \\
\hline & & & & 倒壊 & 小破 & 大破 & $\begin{array}{l}\text { 小破 } \\
\end{array}$ & 大破 & 小破 & 大破 & 大破 & 大破 & $\begin{array}{l}\text { 小破 } \\
\end{array}$ & $\begin{array}{l}\text { 小破 } \\
\end{array}$ & $\begin{array}{l}\text { 小破 } \\
\end{array}$ & 大破 \\
\hline & \multirow{6}{*}{ JMA神戸 } & \multirow{2}{*}{ 2階 } & $\mathrm{x}$ & $1 / 148$ & $1 / 318$ & $1 / 18$ & $1 / 226$ & $1 / 265$ & $1 / 186$ & $1 / 20$ & $1 / 116$ & $1 / 199$ & $1 / 184$ & $1 / 174$ & $1 / 214$ & $1 / 190$ \\
\hline & & & $\mathrm{Y}$ & $1 / 292$ & $1 / 153$ & $1 / 152$ & $1 / 123$ & $1 / 219$ & $1 / 183$ & $1 / 41$ & $1 / 134$ & $1 / 213$ & $1 / 81$ & $1 / 140$ & $1 / 90$ & $1 / 212$ \\
\hline & & \multirow{4}{*}{ 1階 } & $\mathrm{x}$ & $1 / 38$ & $1 / 23$ & $1 / 39$ & $1 / 18$ & $1 / 19$ & $1 / 15$ & $1 / 32$ & $1 / 14$ & $1 / 12$ & $1 / 15$ & $1 / 17$ & $1 / 19$ & $1 / 14$ \\
\hline & & & & 小破 & 中破 & 小破 & 中破 & 中破 & 大破 & 小破 & 大破 & 大破 & 大破 & 中破 & 中破 & 大破 \\
\hline & & & $\mathrm{Y}$ & $1 / 10$ & $1 / 19$ & $1 / 16$ & $1 / 45$ & $1 / 15$ & $1 / 28$ & $1 / 22$ & $1 / 14$ & $1 / 23$ & $1 / 29$ & $1 / 32$ & $1 / 25$ & $1 / 16$ \\
\hline & & & & 大破 & 中破 & 中破 & 小破 & 大破 & 中破 & 中破 & 大破 & 中破 & 中破 & 小破 & 中破 & 中破 \\
\hline \multirow{12}{*}{ 補強後 } & \multirow{6}{*}{ BCJ-EVEL2 } & \multirow{2}{*}{ 2階 } & $\mathrm{X}$ & $1 / 169$ & $1 / 163$ & $1 / 16$ & $1 / 158$ & $1 / 123$ & $1 / 49$ & $1 / 18$ & $1 / 10$ & $1 / 147$ & $1 / 101$ & $1 / 106$ & $1 / 133$ & $1 / 82$ \\
\hline & & & $\mathrm{Y}$ & $1 / 151$ & $1 / 133$ & $1 / 28$ & $1 / 123$ & $1 / 128$ & $1 / 138$ & $1 / 16$ & $1 / 25$ & $1 / 100$ & $1 / 64$ & $1 / 144$ & $1 / 113$ & $1 / 101$ \\
\hline & & \multirow{4}{*}{ 1階 } & $\mathrm{X}$ & $1 / 71$ & $1 / 40$ & $1 / 74$ & $1 / 54$ & $1 / 63$ & $1 / 115$ & $1 / 137$ & $1 / 36$ & $1 / 52$ & $1 / 126$ & $1 / 157$ & $1 / 121$ & $1 / 81$ \\
\hline & & & & 小破 & 小破 & 小破 & 小破 & 小破 & 小破 & 小破 & 小破 & 小破 & 小破 & 軽微 & 小破 & 小破 \\
\hline & & & Y & $1 / 53$ & $1 / 36$ & $1 / 75$ & $1 / 76$ & $1 / 53$ & $1 / 107$ & $1 / 81$ & $1 / 39$ & $1 / 40$ & $1 / 381$ & $1 / 221$ & $1 / 119$ & $1 / 53$ \\
\hline & & & & 小破 & 小破 & 小破 & 小破 & 小破 & 小破 & 小破 & 小破 & 小破 & 無被害 & 軽微 & 小破 & 小破 \\
\hline & \multirow{6}{*}{ JMA神戸 } & \multirow{2}{*}{ 2階 } & $\mathrm{X}$ & $1 / 148$ & $1 / 163$ & $1 / 13$ & $1 / 151$ & $1 / 110$ & $1 / 32$ & $1 / 15$ & $1 / 10$ & $1 / 126$ & $1 / 50$ & $1 / 47$ & $1 / 45$ & $1 / 86$ \\
\hline & & & $\mathrm{Y}$ & $1 / 146$ & $1 / 153$ & $1 / 16$ & $1 / 123$ & $1 / 107$ & $1 / 122$ & $1 / 14$ & $1 / 67$ & $1 / 35$ & $1 / 81$ & $1 / 119$ & $1 / 90$ & $1 / 73$ \\
\hline & & \multirow{4}{*}{ 1階 } & $\mathrm{X}$ & $1 / 38$ & $1 / 21$ & $1 / 40$ & $1 / 32$ & $1 / 47$ & $1 / 86$ & $1 / 103$ & $1 / 26$ & $1 / 39$ & $1 / 86$ & $1 / 117$ & $1 / 77$ & $1 / 51$ \\
\hline & & & & 小破 & 中破 & 小破 & 小破 & 小破 & 小破 & 小破 & 中破 & 小破 & 小破 & 小破 & 小破 & 小破 \\
\hline & & & $\mathrm{Y}$ & $1 / 32$ & $1 / 19$ & $1 / 29$ & $1 / 45$ & $1 / 32$ & $1 / 60$ & $1 / 57$ & $1 / 18$ & $1 / 19$ & $1 / 234$ & $1 / 149$ & $1 / 25$ & $1 / 40$ \\
\hline & & & & $\begin{array}{l}\text { 小破 } \\
\end{array}$ & $\begin{array}{l}\text { 中破 } \\
\end{array}$ & $\begin{array}{l}\text { 中破 } \\
\end{array}$ & $\begin{array}{l}\text { 小破 } \\
\end{array}$ & 小破 & $\begin{array}{l}\text { 小破 } \\
\end{array}$ & $\begin{array}{l}\text { 小破 } \\
\end{array}$ & $\begin{array}{l}\text { 中破 } \\
\end{array}$ & $\begin{array}{l}\text { 中破 } \\
\end{array}$ & 軽微 & $\begin{array}{l}\text { 小破 } \\
\end{array}$ & $\begin{array}{l}\text { 中破 } \\
\end{array}$ & 小破 \\
\hline
\end{tabular}

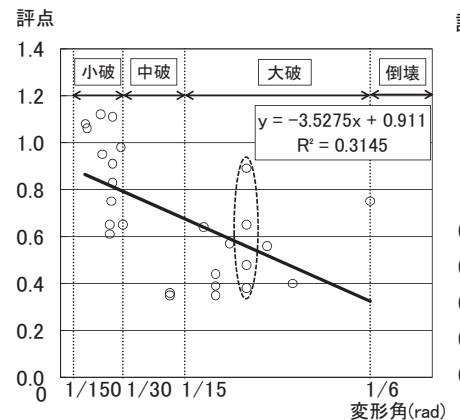

図 16 1 階における評点と応答 層間変形角（補強前の建物）

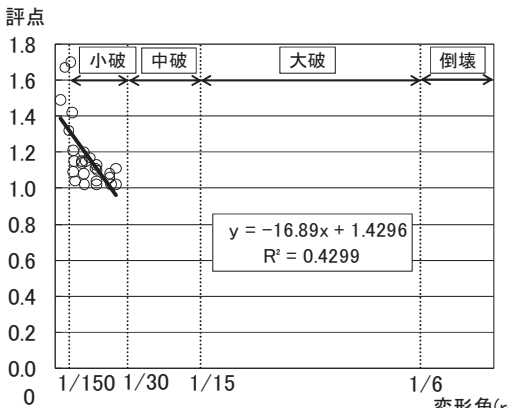

図 171 階における評点と応答 層間変形角 (補強後の建物)

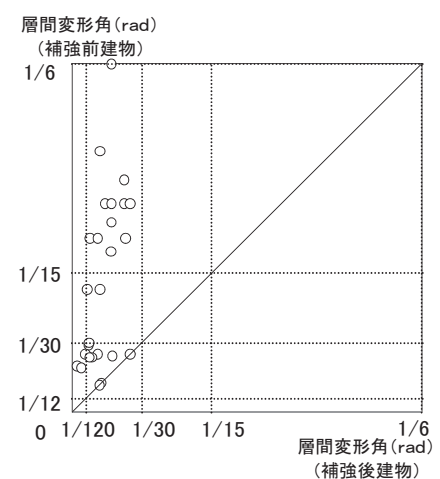

図 18 補強前後の

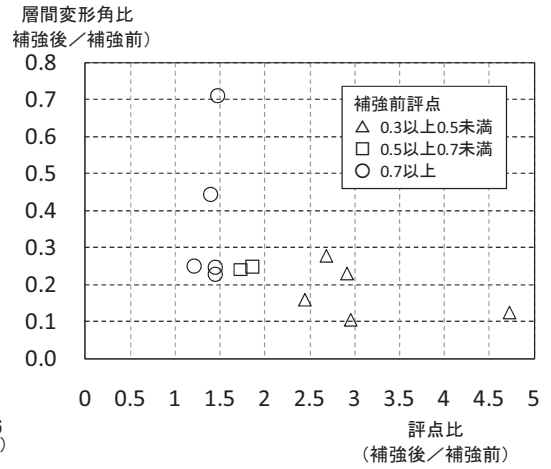

1 階応答層間変形角の比較

図 19 補強前と補強後の 1 階

における評点比と応答層間変形角

す。補強後建物の補強前建物に対する評点比が上昇するほど最大応 答層間変形角比は減少, 寸なわち補強後の層間変形角は小さくなっ ている。層間変形角比は，ほぼ 0 から 0.5 の範囲になっている。

\section{4. 最大応答層間変形角に応じた地震被害レベルの推定}

地震被害の推定方法について, いくつかの論文が出されている。 岡田・高井は, 東京都防災会議の震度階解説表の被害記録を, 震度

表 4 損傷度と層間変形角, 被害レベル

\begin{tabular}{|c|c|c|c|c|c|c|c|}
\hline 損傷度 & 1 & 2 & 3 & & 4 & 5 & 6 \\
\hline 層間変形角 & \multicolumn{2}{|c|}{$1 / 300$} & \multicolumn{3}{|c|}{$1 / 30$} & \multicolumn{2}{|c|}{$1 / 6$} \\
\hline 被害レベル & $\begin{array}{l}\text { 無被害 } \\
\end{array}$ & 軽微 & 小破 & & 中破 & 大破 & 倒壊 \\
\hline
\end{tabular}

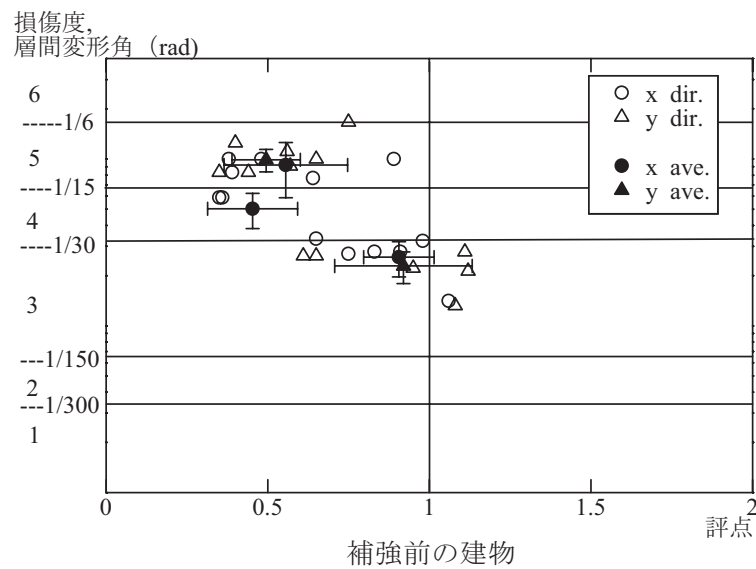

損傷度,

補強前の建物

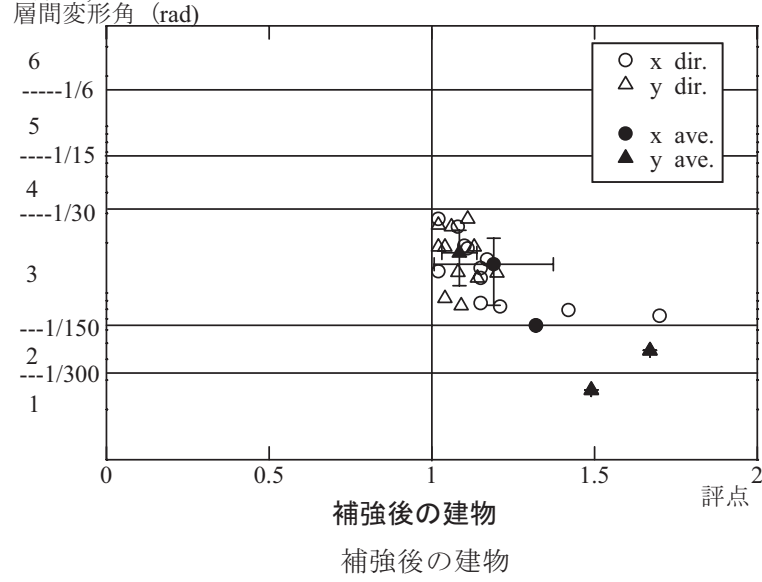

図 20 補強の有無による評点と損傷度 
と被害率に関する防災エキスパートの知識とみなし, 震度と被害率 の関係として被害関数を提案している ${ }^{2}$ 。 つづいて個別建物の耐震 診断值を保有強度の代表值として用い, 個々の建物の被害程度を評 価する損傷度関数を提案している ${ }^{6}$ 。花井 ・皆川は, 時刻歴応答解 析による最大応答層間変形角に応じた損傷モードを作成している7) 田端・大橋は, 1995 年兵庫県南部地震の被害状況から被災度の判定 を行い, 評点と被災度の関係を示している ${ }^{4)}$ 。井戸田・梅村らは, 時刻歷応答解析による最大応答層間変形角に応じた損傷度を定義し, 岡田・高井論文による被害率関数との整合性を検証し, 損傷度と被 害率関数とが比較的良い対応を示していると報告している 8)。中 村・前田らは, 限界耐力計算手法を用い, 被災度別被害関数（被災 度と地震動強さの関係）を提案している ${ }^{9)}$ 。林らは, 限界耐力計算 手法を用い, 経年劣化を考慮可能にした地震時損傷度予測手法を提 案している ${ }^{10)}$ 。境・飯塚は, 地震発生確率に全壊被害額を乗じたも のを期待損失額として費用対効果を算定している ${ }^{11}$ 。五十田らは, 模擬地震動を建物モデルに入力し, 得られた最大層間変位より損傷 費用を求めている。層間変形角に応じた被害レベルを定め, かつ, 2004 年新潟県中越地震の悉皆調查（日本建築学会報告）に基づき, 建替え・補修の比率も考慮して損傷費用を定めている。家財の損傷 費用も加算されている。12)

本論文では，五十田らの論文 12, 14) をそのまま引用して, 時刻歴 応答解析による 1 階最大応答層間変形角に応じた地震被害レベルを 表 4 のように規定する。五十田らは実大実験により, 相関変形角に 応じた地震被害レベルを確認している。12) ここで図 16, 17 で示し た関係を, 評点と層間変形角に応じた損傷度との関係として再整理 して, 図 20 に示す。損傷度ごとに平均值を黒塗りマークで示し, 標準偏差をエラーバーで示す。いずれも評点が上がる程損傷度が低 くなる傾向が認められる。これは, 大橋らの結果と調和的である4)。

建物の被害レベルと費用割合, 及び補修・建替え割合は, 五十田 ら 12) と同じく, 表 5 に示す值とする。費用割合とは新築時に必要 な費用に対する補修費用の割合のことである。被害レベルが大きく なるほど, 費用割合が大きくなっており, 軽微の場合は, 費用割合 が少なく $2 \%$ としているが, 大破は初期費用と同額として $100 \%$ と している。また, 軽微な被害であっても, 地震後わずかではあるが 建替えを行っている実情もあることから, 別に復旧状況割合を定め
表 5 層間変形と損傷費用

\begin{tabular}{|c|c|c|c|c|c|c|c|}
\hline \multirow{2}{*}{ 被害レベル } & 基準 & \multicolumn{2}{|c|}{$\begin{array}{l}\text { 無被害 } \\
\end{array}$} & 一部損傷 & 半壊 & \multicolumn{2}{|c|}{ 全壊 } \\
\hline & 本論 & 無被害 & 軽微 & 小破 & 中破 & 大破 & 倒壊 \\
\hline 層間変形角 & $\mathrm{rad}$ & \multicolumn{2}{|c|}{$1 / 300$} & \multicolumn{2}{|c|}{$1 / 30$} & \multicolumn{2}{|c|}{$1 / 6$} \\
\hline \multirow{2}{*}{$\begin{array}{c}\text { 費用 } \\
\text { 割合 }(\%) \\
\end{array}$} & 補修 & 0.0 & 2.0 & 10.0 & 50.0 & 100.0 & 100.0 \\
\hline & 建替 & 100.0 & 100.0 & 100.0 & 100.0 & 100.0 & 100.0 \\
\hline \multirow{2}{*}{$\begin{array}{c}\text { 復旧 } \\
\text { 状況 (\%) } \\
\end{array}$} & 補修 & 96.0 & 96.0 & 78.4 & 37.8 & 0.0 & 0.0 \\
\hline & 建替 & 4.0 & 4.0 & 21.6 & 61.3 & 100.0 & 100.0 \\
\hline 費用 & $\%$ & 4.0 & 5.9 & 29.5 & 80.6 & 100.0 & 100.0 \\
\hline \multicolumn{2}{|c|}{ 建物損傷費 $\left(円 / \mathrm{m}^{2}\right)$} & 6,040 & 8,909 & 44,545 & 121,706 & 151,000 & 151,000 \\
\hline \multicolumn{2}{|c|}{ 家財損傷費 $\left(\right.$ 円 $\left./ \mathrm{m}^{2}\right)$} & 1,600 & 2,360 & 11,800 & 32,240 & 40,000 & 80,000 \\
\hline
\end{tabular}
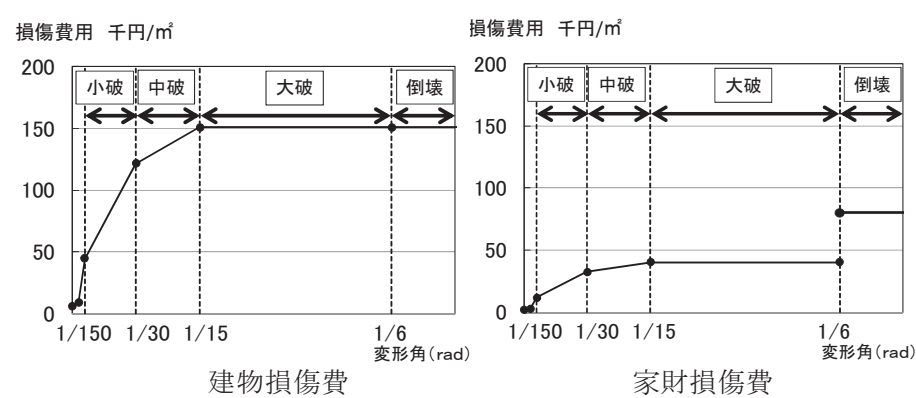

図 21 応答層間変形角之損傷費用

ている。例えば，軽微の場合は，96\%の建物が補修しており，4\% の建物が建替えされているものとしており，大破の場合は，補修さ れるものが $0 \%$ で, $100 \%$ が建替えされているものとしている。これ らの数值は, 2004 年新潟県中越地震の悉皆調査 (日本建築学会 2004 年 10 月 23 日新潟県中越地震災害調查報告 2006.8）から, 五十田 らが計算した数值である。補修費用割合と復旧状況割合を考慮して, 被害レベルに応じた損傷費用割合（初期費用に対する必要改修費用 の比）を計算している。即ち, 軽微の場合, 96.0 (復旧割合) $\times 0.02$ (費用割合) +4.0 (復旧割合) $\times 1.00$ (費用割合) $=5.92 \%$ となる。 大破，倒壊の場合は，100\%建替えとなり，損傷費用割合は $100 \%$ と なる。損傷費用割合を表 5 の「費用 $(\%) 」$ 欄に記入している。

\section{5. 地震被害レベルと必要改修工事費との関係}

地震被害レベルと損傷費との関係を表 5 の建物損傷費・家財損傷 費欄に記入し，その数值を図 21 にグラフ化している。

表 6 補強工事費と必要改修工事費

\begin{tabular}{|c|c|c|c|c|c|c|c|c|c|c|c|c|c|c|c|c|c|}
\hline \multicolumn{5}{|c|}{ No. } & 1 & 2 & 3 & 4 & 5 & 6 & 7 & 8 & 9 & 10 & 11 & 12 & 13 \\
\hline \multicolumn{4}{|c|}{ 補強工事費 } & $\mathrm{f} / \mathrm{m}^{2}$ & 4,707 & 2,028 & 19,720 & 5,945 & 8,633 & 23,503 & 46,726 & 5,675 & 8,846 & 13,263 & 14,202 & 10,874 & 17,531 \\
\hline \multirow{18}{*}{$\begin{array}{l}\text { 必 } \\
\text { 要 } \\
\text { 改 } \\
\text { 修 } \\
\text { 工 } \\
\text { 事 } \\
\text { 費 }\end{array}$} & \multirow{8}{*}{$\begin{array}{l}\text { 事前 } \\
\text { 補强 }\end{array}$} & \multirow{4}{*}{ BCJ LEVEL-2 } & 建物改修費 & 円 $/ \mathrm{m}^{2}$ & 25,214 & 37,121 & 18,059 & $\begin{array}{l}24,747 \\
\end{array}$ & 25,214 & 12,489 & $\begin{array}{ll}16,498 \\
\end{array}$ & 37,121 & $\begin{array}{c}33,409 \\
\end{array}$ & 10,606 & 2,613 & 11,230 & 25,214 \\
\hline & & & 家財改修費 & $\mathrm{m} / \mathrm{m}^{2}$ & 6,679 & \begin{tabular}{l|l|}
9,833 \\
\end{tabular} & 4,784 & 6,556 & 6,679 & 3,308 & 4,370 & 9,833 & 8,850 & 2,810 & 692 & 2,975 & 6,679 \\
\hline & & & 合計 & $\mathrm{f} / \mathrm{m}^{2}$ & 36,600 & \begin{tabular}{l|l|l}
48,982 & \\
\end{tabular} & 42,563 & 37,248 & \begin{tabular}{l|l}
40,526 \\
\end{tabular} & \begin{tabular}{|l|}
39,301 \\
\end{tabular} & $\begin{array}{ll}67,595 \\
\end{array}$ & 52,629 & 51,105 & \begin{tabular}{l|}
26,678 \\
\end{tabular} & \begin{tabular}{l|l}
17,507 \\
\end{tabular} & 25,079 & 49,424 \\
\hline & & & 合計金額 & 千円 & 4,121 & 6,207 & 6,588 & 3,239 & 5,680 & 3,629 & 8,228 & 7,975 & 6,602 & 2,695 & 1,841 & 2,471 & 5,812 \\
\hline & & \multirow{4}{*}{ JMA神戸 NS } & 建物改修費 & 円 $/ \mathrm{m}^{2}$ & 41,761 & \begin{tabular}{l|l|}
89,217 \\
\end{tabular} & 47,206 & 41,761 & 41,761 & 22,273 & 23,445 & 89,217 & 95,986 & 15,539 & 11,422 & \begin{tabular}{|l|}
59,977 \\
\end{tabular} & 33,409 \\
\hline & & & 家財改修費 & 丹 $/ \mathrm{m}^{2}$ & 11,063 & 23,634 & 12,505 & $\begin{array}{ll}11,063 \\
\end{array}$ & 11,063 & 5,900 & 6,211 & 23,634 & 25,427 & 4,116 & 3,026 & 15,888 & 8,850 \\
\hline & & & 合計 & $\mathrm{p} / \mathrm{m}^{2}$ & 57,530 & 114,879 & \begin{tabular}{|c|}
79,431 \\
\end{tabular} & \begin{tabular}{|l|l|}
58,768 \\
\end{tabular} & 61,456 & $\begin{array}{ll}51,676 \\
\end{array}$ & \begin{tabular}{ll|}
76,381 \\
\end{tabular} & 118,526 & 130,258 & 32,918 & 28,649 & 86,739 & 59,790 \\
\hline & & & 合計金額 & 千円 & 6,477 & \begin{tabular}{l|l|}
14,557 &
\end{tabular} & 12,294 & 5,111 & 8,614 & \begin{tabular}{l|l|}
4,771 & \\
\end{tabular} & 9,298 & 17,961 & 16,828 & 3,326 & \begin{tabular}{l|l|}
3,013 \\
\end{tabular} & 8,547 & 7,031 \\
\hline & \multirow{10}{*}{$\begin{array}{l}\text { 事前 } \\
\text { 補強無 }\end{array}$} & \multirow{5}{*}{ BCJ LEVEL-2 } & 建物改修費 & $\mathrm{f} / \mathrm{m}^{2}$ & 151,000 & \begin{tabular}{|l|}
131,471 \\
\end{tabular} & 138,794 & \begin{tabular}{|l|l|}
124,711 \\
\end{tabular} & \begin{tabular}{|l|}
131,471 \\
\end{tabular} & \begin{tabular}{l|l|}
126,588 \\
\end{tabular} & 126,588 & 131,471 & 134,726 & 43,108 & 37,121 & 44,545 & 131,471 \\
\hline & & & 家財改修費 & 円 $/ \mathrm{m}^{2}$ & 80,000 & \begin{tabular}{ll|}
34,827 \\
\end{tabular} & $\begin{array}{ll}36,767 \\
\end{array}$ & 33,036 & $\begin{array}{ll}34,827 \\
\end{array}$ & 33,533 & 33,533 & $\begin{array}{ll}34,827 \\
\end{array}$ & 35,689 & 11,419 & $\begin{array}{ll}9,833 \\
\end{array}$ & 11,800 & 34,827 \\
\hline & & & 合計 & 丹 $/ \mathrm{m}^{2}$ & 231,000 & 166,297 & 175,561 & 157,746 & 166,297 & 160,122 & 160,122 & 166,297 & 170,414 & 54,527 & 46,954 & 56,345 & 166,297 \\
\hline & & & 金額(千円) & 千月 & 26,008 & \begin{tabular}{l|l|}
21,073 & \\
\end{tabular} & 27,173 & 13,718 & 23,308 & 14,784 & 19,492 & 25,201 & 22,016 & \begin{tabular}{l|l|}
5,509 \\
\end{tabular} & \begin{tabular}{l|l|}
4,938 \\
\end{tabular} & 5,552 & 19,555 \\
\hline & & & 前/後 & 比 & 6.31 & 3.40 & 4.12 & 4.24 & 4.10 & 4.07 & 2.37 & \begin{tabular}{l|l|}
3.16 \\
\end{tabular} & 3.33 & 2.04 & 2.68 & 2.25 & 3.36 \\
\hline & & \multirow{5}{*}{ JMA神戸 NS } & 建物改修費 & $\mathrm{f} / \mathrm{m}^{2}$ & 131,471 & 112,061 & 112,061 & $\begin{array}{l}95,986 \\
\end{array}$ & 121,706 & 121,706 & 72,604 & 123,101 & 126,588 & 121,706 & 103,550 & 89,217 & 123,101 \\
\hline & & & 家財改修費 & 丹 $/ \mathrm{m}^{2}$ & \begin{tabular}{ll|}
34,827 \\
\end{tabular} & \begin{tabular}{l|l}
29,685 \\
\end{tabular} & 29,685 & 25,427 & 32,240 & 32,240 & 19,233 & 32,610 & 33,533 & 32,240 & 27,431 & 23,634 & 32,610 \\
\hline & & & 合計 & 円 $/ \mathrm{m}^{2}$ & 166,297 & \begin{tabular}{l|l|}
141,746 \\
\end{tabular} & 141,746 & 121,412 & 153,946 & \begin{tabular}{l|l|}
153,946 \\
\end{tabular} & 91,836 & 155,710 & 160,122 & 153,946 & 130,981 & 112,851 & 155,710 \\
\hline & & & 金額(千円) & 千丹 & 18,723 & \begin{tabular}{ll|}
17,962 \\
\end{tabular} & 21,939 & 10,558 & 21,577 & 14,214 & 11,179 & 23,596 & 20,686 & 15,553 & 13,775 & 11,120 & 18,310 \\
\hline & & & 前/後 & 比 & 2.89 & \begin{tabular}{l|l}
1.23 \\
\end{tabular} & 1.78 & 2.07 & 2.50 & 2.98 & 1.20 & \begin{tabular}{ll|}
1.31 \\
\end{tabular} & \begin{tabular}{l|l}
1.23 \\
\end{tabular} & \begin{tabular}{|l|}
4.68 \\
\end{tabular} & \begin{tabular}{|l|}
4.57 \\
\end{tabular} & \begin{tabular}{ll|}
1.30 \\
\end{tabular} & 2.60 \\
\hline
\end{tabular}


建物の地震被害による改修の必要性は, 主に, 1 階の損傷程度に よって決定されることが多いと考え, 本論文では, 1 階の地震被害 レベルを用いて, 必要改修工事費全体を算定することとしている。 1 階 $\mathrm{X}$ 方向と $\mathrm{Y}$ 方向の必要改修工事費が異なる場合は, 大きい方の 費用を採用することとしている。

損傷費用とは地震後の必要改修費用のことで,これを本論文では, 必要改修工事費という。また, 一般的な木造住宅の建築初期費用を 151,000 円 $/ \mathrm{m}^{2}$ と仮定する。家財初期費用は五十田ら 12) と同様にし て, 一人当たり 300 万円とし, 4 人家族 1200 万円とする。床面積 当たりでは 1200 万円 $/ 150 \mathrm{~m}^{2}=8$ 万円 $/ \mathrm{m}^{2}$ となる。それぞれの単価に 費用（\%）を掛けて, 各点 (小破, 中破, 大破) の建物損傷費・家 財損傷費を算出する。表 5 の中の建物損傷費を算定してみると、例 えば、小破の最大值は費用（\%）29.5\%に建築初期費用 151,000 円 $/ \mathrm{m}^{2}$ を乗じて 44,545 円/ $\mathrm{m}^{2}$ となり，中破の最大值は費用（\%） $80.6 \%$ に建築初期費用 151,000 円 $/ \mathrm{m}^{2}$ を乗じて 121,706 円 $/ \mathrm{m}^{2}$ となる。それ ぞれの中間の值は直線補間とする。小破から大破までの家財の費用 （\%）は，建築の費用（\%)の $1 / 2$ とし, 倒壊では $1 / 1$ とする。文 献 16 において, 家財の損傷割合は, 一部損・半壊で $15 \%$, 全損で $30 \%$ となっており, 本論文と近似している。即ち, 小破の最大值は, 費用 (\%) 29.5\%の $1 / 2$ に家財初期費用 80,000 円/ $\mathrm{m}^{2}$ を乗じて 11,800 円 $/ \mathrm{m}^{2}$ となり, 中破の最大值は費用（\%） $80.6 \%$ の $1 / 2$ に家財初期費 用 80,000 円 $/ \mathrm{m}^{2}$ を乗じて 32,240 円 $/ \mathrm{m}^{2}$ となる。

\section{6. 各建物ごとの補強工事費と必要改修工事費}

各建物ごとの補強工事費と必要改修工事費を表 6 に示寸。事前補 強有の建物の総工事費（補強工事費十必要改修工事費）が事前補強 無建物の必要改修工事費よりも小さければ, 即ち, 必要改修工事費/ 総工事費 $\geqq 1.0$ であれば補強効果があるということになる。

表 6 において, 建物NNo.5 を例にとり, 該当欄に影を付けて数值を示 寸。事前補強有の場合, 補強工事費は 8,633 円 $/ \mathrm{m}^{2}$, 建物改修費は 25,214 円 $/ \mathrm{m}^{2}$, 家財改修費は 6,679 円 $/ \mathrm{m}^{2}$, それらの合計として総工 事費は 40,526 円 $/ \mathrm{m}^{2}$ となる。一方, 事前補強無とした場合, 建物改 修費は $131,471 \mathrm{~m} / \mathrm{m}^{2}$, 家財改修費は $34,827 \mathrm{~m} / \mathrm{m}^{2}$, それらの合計と して必要改修工事費は 166,297 円 $/ \mathrm{m}^{2}$ となる。この結果を用いると, 必要改修工事費/総工事費 $=166,297 / 40,526=4.10$ となり, 事前補強 の効果が確認される。このようにして得られた 13 棟について必要 改修工事費と総工事費との関係を図 22 に示寸。

さらに, 総工事費に対する必要改修工事費の割合である工事費比 率を求め, これと補強前の評点との関係を図 23 に示す。表 6 、図 23 から, 工事費比率は $2.04 \sim 6.31$, 平均值は 3.26 となっている。 補強無の場合の評点が低いほど (弱い建物ほど), 耐震補強効果が高 いと予測していたが，この図では明確な関係が見出せない。補強無 の場合の評点が高い 2 棟（建物NNo.10,11）は工事費比率が低い，す なわち, 補強効果が低いという結果になっている。工事費比率が 6.31 と高い建物№.1 は耐震補強費が非常に低価格であったことから， 必要改修工事費/総工事費が高くなっている。

\section{7. 耐震補強有建物の費用対効果}

以上のまとめとして, 図 24 に, 耐震補強有建物の費用対効果を 示す。傾向をわかりやすく把握するために，横軸を 2-3-3 で定義し

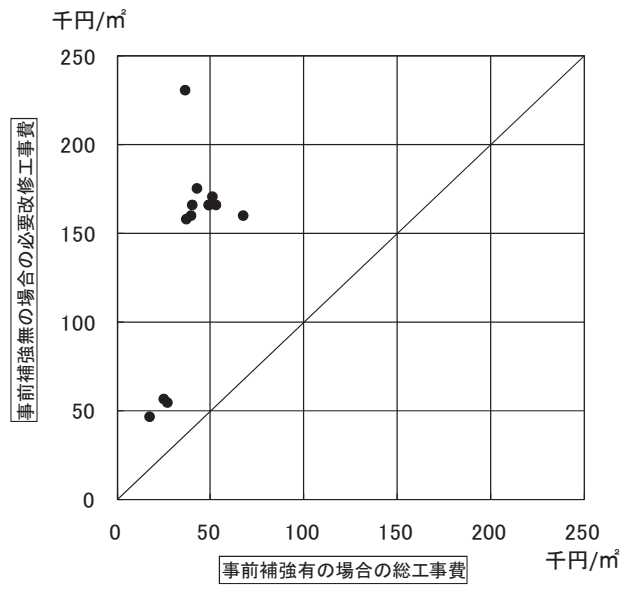

図 22 事前補強有の場合の総工事費に 対する事前補強無の場合の改修工事費

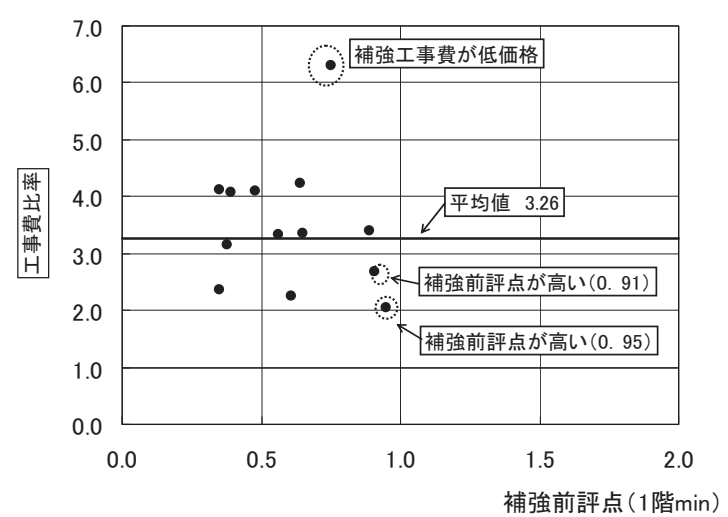

図 23 補強前評点と工事費比率

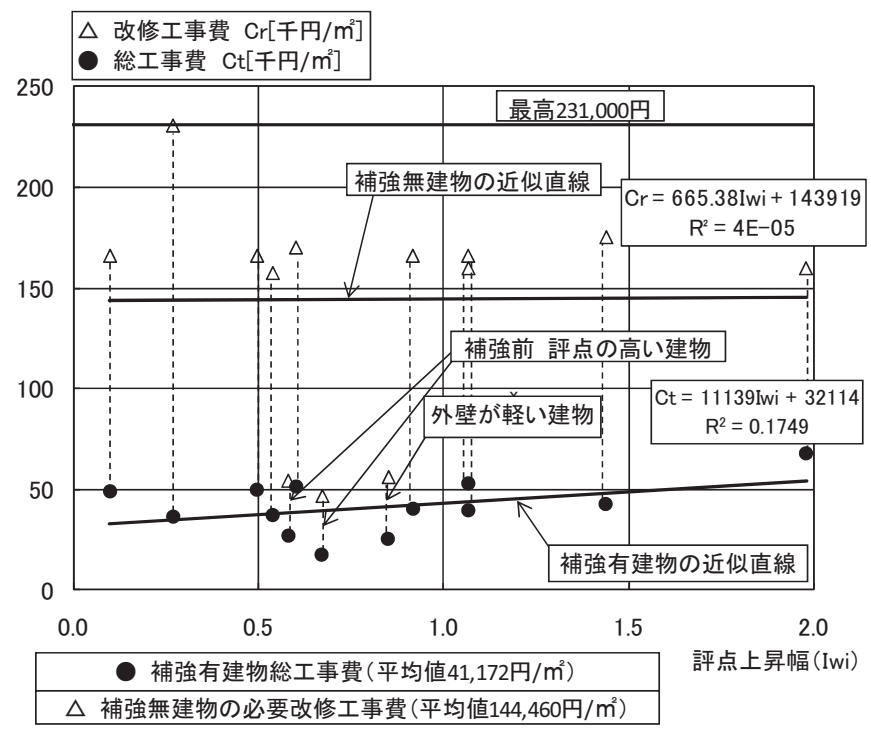

図 24 補強無建物の必要改修工事費と補強有建物の総工事費

た評点上昇幅，縦軸を補強無建物の必要改修工事費 $\left(\right.$ 円 $\left./ \mathrm{m}^{2}\right)$ および 補強有建物の総工事費 $\left(\right.$ 円 $\left./ \mathrm{m}^{2}\right)$ と寸る。而震補強を行っていない建 物（補強無建物）を $\triangle$ ，耐震補強を行った建物（補強有建物）を と表示している。 ことを表す。

補強無建物の必要改修工事費平均值は 144,460 円 $/ \mathrm{m}^{2}$, 補強有建物 
の総工事費平均值は 41,172 円 $/ \mathrm{m}^{2}$ となっている。工事費の平均值の 割合は $144,460 / 41,172=3.51$ となっている。すべての建物において, 補強有建物の総工事費が補強無建物の必要改修工事費を下回ってお り, 事前に補強工事を行うことによって, 費用対効果が, 有効であ るということが確認できる。

補強無建物の評点が高い建物は費用対効果が低く（必要改修工事 費1総工事費 $=2.02 ， 2.68 ）$ なっている。これは，もともと評点の高 い建物は, 補強後の損傷度に差が少ないためである（補強の有無に よらず小破となっている)。

外壁が鉄板波板の軽い建物も費用対効果が低く, 必要改修工事費I 総工事費 $=2.25$ となっている。

本論文で報告した建物は, 補強後, 大地震に遭遇した時, 試算結 果では全て小破となり, 倒壊しないとなっている。しかし, 倒壊し ない場合であっても被害建物の改修工事費用は必要となる。そのこ とを，住民に事前に説明しておく必要がある。

\section{8. まとめ}

以上, 耐震補強を行った建物と耐震補強を行わなかった建物の地 震災害における費用対効果について, 実例 13 棟を用いて試算した 結果を明らかにした。

- 耐震診断, 補強設計, 補強工事資料より, 評点上昇幅（Iwi）と耐 震補強工事費との相関関係を求め, 単位面積当り補強工事費 $\mathrm{Cr}$ (千 円 $\left./ \mathrm{m}^{2}\right)=17685$ Iwi （相関係数 $\mathrm{r}=0.82 ）$ となっていることを示した (図 8)。

・各建物の復元力特性を耐力要素の重社合わせにより作成し，時刻 歴応答解析を行い, 1,2 階最大応答層間変形角を求め, 層間変形角 に応じた損傷度を計算して, 必要改修工事費を算定した（図 13, 表 3 , 図 21,表 6)。

・耐震補強を行っていない建物の必要改修工事費が, 耐震補強を行 っている建物の総工事費（事前に行った耐震補強工事費と必要改修 工事費を合計したもの) を上回っており, その比率は $2.04 \sim 6.31$ と なっていて，すべての建物の費用対効果が認められた（図 23）。

・評点上昇幅 (Iwi) が大きくなると総工事費 $\left(\right.$ 円 $\left./ \mathrm{m}^{2}\right)$ は少し増加 する。総工事費 $\mathrm{Ct}\left(\right.$ 円 $\left./ \mathrm{m}^{2}\right)=11139 \mathrm{Iw} \mathrm{i}+32114\left(\mathrm{~m} / \mathrm{m}^{2}\right) （$ 相関係 数 $\mathrm{r}=0.42 ）$ となっている（図 24）。

- 必要改修工事費の平均值は $144,460\left(\right.$ 円 $\left./ \mathrm{m}^{2}\right)$, 総工事費の平均值 は $41,172\left(\right.$ 円 $\left./ \mathrm{m}^{2}\right)$ であり, その比率は $144,460 / 41,172=3.51$ とな っている（図 24）。

・補強前評点が高い建物や外壁が軽量の建物は比較的費用対効果が 低くなっている（図 24）。逆を言えば相対的に耐震性能の低い建物 の費用対効果は高いこととなっている。

本論文では, 建設地, 地震発生予測率, 経年劣化, 地震レベルな どの要素が考慮されていないので, あくまでも, 事前補強すべきか どうかの比較検討用資料として報告したものである。資料が少ない が，概ねの傾向は確認できた。

今後資料を増やし, 建設地など, 他の要素を加味しながら, さら に費用対効果について研究を進めなければならないと考えている。

\section{謝辞}

本論文を作成するにあたり，河合直人建築研究所構造研究グルー プ上席研究員, 五十田博信州大学准教授に貴重な助言を頂きました。 耐震診断・補強に関して, 財団法人日本建築防災協会から貴重な助 言を頂きました。費用対効果などに関する資料収集にあたって神田 亮日本大学教授のご協力を頂きました。資料整理を行うに当たり， 板橋清子 $\mathrm{Ai}$ 設計所長のご協力を頂きました。助言, ご協力頂きま した各位に感謝の意を表します。最後に，本論文の整理に協力して 頂いた, 深谷将太郎君（宇都宮大学修士課程）, 北村謙太郎君（宇都 宮大学学部 4 年) に感謝します。

\section{参考文献}

1)財団法人日本建築防災協会 : 木造住宅の耐震診断と補強方法-木造住宅の耐 震精密診断と補強方法（改訂版）

2)岡田成幸，高井伸雄：地震被害調査のための建物分類と破壊パターン，日 本建築学会構造系論文集，第 524 号，pp.65-72，1999.10

3)五十田博: 平成 16 年新潟県中越地震における木造住宅の被害, 日本建築学 会北陸支部研究報告集，第 48 号，pp.33-36，2005.7

4)田端千夏子, 大橋好光 : 木造建築物の而震診断法に関寸る研究-新旧耐震診 断の比較㧍よび評点と被災度の関係-，日本建築学会構造系論文集，第 599 号, pp.119-125，2006.1

5)狩谷のぞみ, 村尾修, 熊谷良雄, 系井川栄一: 実データに基づく而震補強 費用の実態と而震性能向上効果, 地域安全学会論文集, 地域安全学会, No. 7,pp.263-272, 2005.11

6)岡田成幸，高井伸雄 : 木造建築物の損傷度関数の提案と地震防災一の適用地震動入力を確定的に扱う場合，日本建築学会構造系論文集，第 582 号, pp.31-38, 2004.8

7)花井勉，福和伸夫，森保宏，皆川隆之：費用対効果を考えた木造住宅の而 震補強設計について, その 1 ,その 2 , 日本建築学会大会学術講演梗概集, 構造III, pp.157-160，2003

8)井戸田秀樹, 嶺岡信悟, 梅村恒, 森保宏 : 在来軸組木造住宅における一般 耐震診断の評点と損傷度の関係 耐震改修促進のための意思決定支援ツー ルに関する研究 (その 1), 日本建築学会構造系論文集, 第 612 号, pp.125-132, 2007.2

9)中村匠，前田匡樹，三辻和弥：宮城県の耐震診断結果に基づく木造住宅被 害関数の構築, 日本建築学会東北支部研究報告会, pp.115-118, 2007.6

10)林康裕, 更谷安紀子, 森井雄史 : 木造住宅の経年劣化と地域地震環境を考 慮した地震時損傷度予測手法, 日本建築学会構造系論文集, 第 615 号, pp.77-84, 2007.5

11)境有紀，飯塚裕暁 : 実際の被害と対応する地震動強さ指標を用いた既存不 適格木造建物の而震補強における費用対効果の検討，その 1 , その 2 , 日本 建築学会大会学術講演梗概集（関東），構造III，pp.375-378，2006.9

12)佐藤基志，五十田博，佐藤友彦，三宅辰哉：木造住宅用耐震補強技術の費 用対効果に関寸る試算, 日本建築学会構造系論文集, 第 637 号, pp.519-526, 2009.3

13)五十田博, 河合直人：木造軸組構法住宅に用いる壁の復元力特性モデル 木造建物の地震動時挙動に関する研究-, 日本建築学会構造系論文集, 第 616 号, pp.157-163, 2007.6

14)高橋雄司, 正木信男, 穴原範, 五十田博 : 地震危険度の高い地域の建物を 対象とした地震リスク・マネジメント，日本建築学会構造系論文集，第 591 号, pp.25-33, 2005.5

15)荒木康弘, 腰原幹雄, 大橋好光, 坂本功 : 木造住宅の地震応答解析のため の復元力モデルに関する研究, 日本建築学会構造系論文集, 第 579 号, pp.79-85, 2004.5

16)金子美香, 吉村昌宏, 今井卓二 : 家財の地震被害予測手法の検討 (その 3 ) 世帯の家財被害額の推定，日本建築学会大会学術講演梗概集（東北），構 造III, pp.317-318, 2009.8

（2010年 7 月 9 日原稿受理，2010年11月29日採用決定） 